\title{
K ZHODE ADJEKTÍVNEHO PRÍVLASTKU SVÄTÝ S VIACNÁSOBNÝM ČLENOM VYJADRENÝM MENAMI SVÄTÝCH (NA PRÍKLADE SPOJENÍ SVÄTÝ CYRIL A METOD - SVÄTÍ CYRIL A METOD) ${ }^{1}$
}

\author{
On the Agreement Between Adjective "svätý" (Saint) \\ and Multiple Word Structures Containing the Names of Saints \\ [Using the Examples "svätý Cyril a Metod" (Saint Cyril and Methodius) \\ and "svätí Cyril a Metod" (Saints Cyril and Methodius)]
}

Patrik Petráš

DOI: 10.17846/CL.2021.14.1.194-208

\begin{abstract}
PETRÁŠ, Patrik. On the Agreement Between Adjective "svätý" (Saint) and Multiple Word Structures Containing the Names of Saints [Using the Examples "svätý Cyril a Metod" (Saint Cyril and Methodius) and "svätí Cyril a Metod" (Saints Cyril and Methodius)]. The article deals with the use of adjective "svätý" (saint) in multiple word structures containing the names of saints. These structures are used mainly in religious texts; the structures "svätý/svätí Cyril a Metod" (Saint/Saints Cyril and Methodius) are frequently used in Slovak religiously and culturally oriented texts, in which the adjective "svätý" (saint) refers to both names. Although Slovak grammar uses both singular and plural forms of the adjective, we decided to carry out a detailed analysis of the usage of both variants. Our aim is to answer the following questions: Which form of adjective "svätý" (saint) is used in religious genres (songs, prayers)? Is the singular form (the form referring to singular number) preferred in religious genres? In the study, we further examined the frequency of singular and plural forms of these constructions on the texts from the Slovak National Corpus (Slovenský národný korpus). Although we primarily investigated the phrase "svätý/svätí Cyril a Metod" (Saint/Saints Cyril and Methodius), its occurrence can be analogically noticed on other examples as well, e. g. "svätý/svätí Peter a Pavol" (Saint/Saints Peter and Paul), svätý/svätí Andrej Svorad a Benedikt (Saint/Saints Andrew Svorad and Benedict), svätá/sväté Perpetua a Felicita" (Saint/Saints Perpetua and Felicity), etc. The analysis showed that the singular form of adjective "svätý" (saint) is almost exclusively used in songs and prayers of litanies, whereas the plural forms of adjective "svätý" (saint), i. e. "svätî" (saints; including all forms of grammatical cases) are more frequently found in the texts from the Slovak National Corpus (Slovenský národný korpus).
\end{abstract}

Keywords: Saint Cyril and Methodius, Saints Cyril and Methodius, adjective, category of agreement, multiple sentence elements

Príspevok vznikol v rámci riešenia projektu UGA UKF v Nitre č. III/7/2021 Problematika zhody adjektívneho prívlastku „svätý"s viacnásobným členom vyjadreným menami svätých. 


\section{1. Úvodné poznámky}

Gramatická kategória mennej zhody (kongruencie) je jednou z konštituujúcich vlastností flektívneho typu jazyka, akým je slovenčina. Podstatou tejto kategórie je, že slovo adjektívneho rázu sa gramaticky podriaduje nadradenému členu v determinatívnej syntagme, a to tak, že tento gramaticky podradený (rozvíjajúci) vetný člen preberie od nadradeného (rozvíjaného) vetného člena gramatické kategórie rodu, čísla a pádu. Formálne sa táto gramatická závislost podradeného vetného člena od nadradeného člena vyjadruje tvarom slova: podstatný opis, (o) podstatnom opise, podstatné opisy, (s) podstatnými opismi; podstatná zásada, (o) podstatnej zásade, podstatné zásady, (s) podstatnými zásadami; podstatné pravidlo, (o) podstatnom pravidle, podstatné pravidlá, (s) podstatnými pravidlami... Toto pravidlo sa pritom nevztahuje len na adjektíva, ale na všetky slová adjektívneho rázu (gramatika tu používa termín adjektíválium), teda aj na niektoré skupiny zámen (ktorý člen, taká istá aplikácia, každé schválenie), čísloviek (prvý úspech, dvojnásobná dl̇̌ka, dvojaké určenie) a slovesných príčastí (opravený rukopis, prečitaná kniha, vyslovené príslovie; veriaci človek, nasledujúca osoba, vyhovujúce kritérium). Zo všetkých uvedených príkladov vyplýva, že určujúce adjektiváliá vyjadrujú rovnaký rod, číslo a pád ako nadradené substantívum.

Určenie správneho tvaru prívlastku rozvíjajúceho substantívum v jazykovej praxi nespôsobuje problémy, ak je rod nadradeného substantíva jednoznačný. ${ }^{2}$ Zložitejšia je situácia, ked’ sa prívlastok vztahuje na viac substantív vytvárajúcich viacnásobný vetný člen, napr. môj otec a mat$k a$. V uvedenom príklade sú dokonca substantíva vo viacnásobnom vetnom člene odlišnej rodovej príslušnosti. Prívlastok môj sa však napriek nekorektnému tvaru v porovnaní s druhým komponentom viacnásobného vetného člena (feminínom matka) vztahuje na oba členy, t. j. aj na maskulínum otec, aj na feminínum matka. Táto konštrukcia predstavuje vlastne prípad elipsy, to znamená, že člen, ktorý je zrejmý z kontextu alebo zo situácie (v tomto prípade z kontextu), sa ako redundantný neuvádza. Použitie spojenia môj otec a moja matka sa ale v tomto prípade nevylučuje, uvedenie prívlastkov v dvoch tvaroch, pričom každý tvar reflektuje gramatické kategórie daného substantíva $\mathrm{z}$ viacnásobného člena, je bežné najmä $\mathrm{v}$ zdôrazňovacej funkcii, pri osloveniach a pod., napr. vážené čitatelky, vážení čitatelia. V slovenčine teda prevláda tendencia zhody prívlastku podla prvej časti viacnásobného člena. Analógiu tu možno vidiet aj pri zhode prísudku s prvým komponentom viacnásobného podmetu, ak sa prísudok nachádza pred viacnásobným podmetom: Vtedy s nami cestovala naša suseda a jej syn Peter (Vaňko 2015, 59). V tejto súvislosti Oravec a Bajzíková (1986, 87-88) dokonca uvádzajú, že singulár v prísudku býva častejší, ak sú členy viacnásobného podmetu určené spoločným singulárovým prívlastkom. ${ }^{3}$

2 Prípady substantív, ktorých rodová príslušnost v jazykovej praxi kolíše (napr. cudzie či pomnožné podstatné mená), v tomto príspevku neberieme do úvahy.

3 Problematika zhody prísudku s viacnásobným podmetom je v skutočnosti zložitejšia, nevylučuje sa ani plurálová podoba prísudku, no na účely tohto príspevku nie je potrebné, aby sme túto problematiku rozoberali podrobnejšie (viac k tomu porov.: Oravec - Bajzíková 1986, 87-88).V kontexte aktuálnych gramatických výskumov možno tiež uviest', že otázka zhody prísudku s viacnásobným podmetom spôsobuje problémy aj v oblasti strojového prekladu z cudzích jazykov (angličtiny, nemčiny) do slovenčiny. Výsledky výskumu v tejto oblasti indikujú, že najfrekvantovanejšie chyby sú v kongruenčnej kategórii zhody v mennom rode (ak je prísudok v tvare minulého času alebo $\mathrm{v}$ kondicionáli, porov. slovesné tvary hovoril, hovorila, hovorilo, resp. aj hovorili), v predikačnej kategórii času, dalej v kongruenčnej kategórii zhody v čísle a osobe. Chybovost’ sa zvyšuje pri preklade viacnásobných vetných členov a komplikovaných syntaktických štruktúr (Welnitzová - Munková - Wrede 2020, 160-172). 


\section{Prívlastok svätý rozvíjajúci viacnásobný člen vyjadrený dvomi menami svätých}

Problematiku kategórie mennej zhody možno aplikovat aj na spojenia prívlastku svätý s menami svätých: svätý Gorazd, (o) svätom Gorazdovi; svätá Anna, (o) svätej Anne atd'. V prípade spojenia uvedeného prívlastku s viacerými menami svätých je potrebné odlišit spojenia s mužskými menami (svätý/svätí Cyril a Metod), spojenia so ženskými menami (svätá/sväté Perpetua a Felicita) a spojenia s mužským i ženským menom (svätý František a Klára). Kedže zmiešané spojenia mužského a ženského mena (napr. svätý František a Klára) nie sú vel’mi časté a v žánri litánií takéto konštrukcie ani neidentifikujeme, nebudeme sa im v tomto príspevku venovat', ide však o už spomínané spojenie typu môj otec a matka.

Ak prívlastok svätý rozvíja dve mužské mená (typ svätý/svätí Cyril a Metod), v hovorenej reči nie sú tvary prívlastku svätý a svätí odlíšitelné, pretože obe podoby sa vyslovujú tvrdo, majú rovnakú hláskoslovnú realizáciu. Rozdiel je tu teda len ortografický. Zrejme aj to je jeden z dôvodov kolísania, resp. väčšej neistoty, ako toto spojenie zapísat správne, preto práve uvedený prípad je hlavným predmetom záujmu tohto príspevku.

Iná by však bola situácia, pokial' by prívlastok svätý rozvíjal dve mená ženského rodu, v tomto prípade by bol rozdiel aj vo zvukovej podobe, porov. napr.: svätá Perpetua a Felicita - sväté Perpetua a Felicita. Ako na to poukážeme d’alej, aj v týchto prípadoch sa v náboženskej literatúre (konkrétne v modlitbe litánií) používa singulárová podoba prívlastku.

Spojeniu adjektívneho prívlastku svätý s menami Cyril a Metod sa už dávnejšie venoval v odpovedi čitatel'ke časopisu Kultúra slova Ivan Masár (1991, 316-317). Autor v odpovedi na otázku, či je správna veta Svätý Cyril a Metod, orodujte za nás! alebo Svätí Cyril a Metod, orodujte za nás! konštatuje, že ide o problém zhody adjektívneho prívlastku s viacnásobným členom vyjadreným podstatnými menami. Pisatelka listu uviedla, že sa v literatúre stretla s obidvoma spôsobmi. I. Masár však dokladoval príkladmi z náboženskej literatúry (o. i. aj z modlitby litánií), ako Svätý Fabián a Šebastián, Svätý Ján a Pavol, Svätý Kozma a Damián, Svätý Gerváz a Protáz, ale i zmieneným príkladom Svätý Cyril a Metod. ${ }^{4}$ Autor teda v analyzovanej náboženskej literatúre zaznamenal iba podoby adjektívneho prívlastku zhodujúceho sa v rode, čísle a páde s prvou častou viacnásobného vetného člena. I. Masár $(1991,317)$ tu tiež podčiarkuje význam tradície v závažných náboženských textoch, a preto odporúča priklonit’ sa k podobe so singulárovou formou prívlastku svätý. Na záver konštatuje, že v slovenčine je možná a prípustná litániová invokácia $\mathrm{k}$ dvom alebo viacerým svätým s prívlastkom svätý v plurálovej podobe, avšak hodnotí ju ako zriedkavú a ako výsledok vplyvu latinskej predlohy, pretože v latinských invokáciách sa slovo svätý používa v množnom čísle (Sancti Petre et Paule, t. j. Svätí Peter a Pavol) (Masár, 1991, 317).

Novšiu reakciu na otázku súvisiacu s touto témou nachádzame v internetovej Jazykovej poradni Jazykovedného ústavu L'udovíta Štúra SAV, v ktorej autori odpovedali na otázku, ako správne čítat skratku sv. v názve školy Katolícka stredná pedagogická škola sv. Cyrila a Metoda. V odpovedi sa rovnako dočítame, že „pri pomenovaní školy, sviatku, pamätníka a pod. podla týchto svätcov prívlastok svätý sa vztahuje na obe mená, preto v príslušnom názve nie je potrebné toto prídavné meno dávat do tvaru množného čísla; jeho použitie je možné, ale nevyžaduje sa" (JazykovaPoradna.sk 2013), a teda správne sú pomenovania Katolícka stredná pedagogická škola svätého Cyrila a Metoda i Katolícka stredná pedagogická škola svätých Cyrila a Metoda (JazykovaPoradna.sk 2013). Kedže sa však v tomto prípade prívlastok svätý nenachádza

4 Pri prepise slova svätý $\mathrm{v}$ uvedených príkladoch rešpektujeme podobu uvádzanú v citovanom článku, ako aj podobu uvádzanú v litániách, t. j. zapisovanie prívlastku Svätýs vellkým začiatočným písmenom. Tento princíp uplatňujeme v celom príspevku, ak citujeme príklady z litánií. 
v základnom tvare, ale je vyskloňovaný, dochádza tu už k rozdielu aj vo zvukovej podobe, rozdiel nie je len v ortografii (porov. vyznačené tvary svätého - svätých). Podobných názvov obsahujúcich prívlastok svätý v spojení s menami viacerých svätých je velmi vela a jedným $\mathrm{z}$ dôvodov, ktoré spôsobujú neistotu, v akom tvare tento prívlastok vyslovit' (príp. písomne uviest’ v úplnej podobe), je najmä to, že sa takmer výlučne uvádza v podobe skratky $s v$., ktorá môže podla kontextu odkazovat na lubovolný pádový tvar z paradigmy slova svätý, teda aj na niektorý z plurálových tvarov, no ako komponent názvu je toto slovo väčšinou limitované len na použitie v genitívnom tvare (singulárovom alebo plurálovom), porov. aj názov Univerzita svätého/svätých Cyrila a Metoda.

\section{Analýza používania spojení svätý Cyril a Metod - svätí Cyril a Metod}

V nasledujúcej časti sa budeme venovat analýze používania singulárových i plurálových variantov prívlastku svätý v spojeniach s viacerými menami svätých. Kedže je však takýchto spojení pomerne vela, budeme analyzovat' spojenie svätý Cyril a Metod, ktoré možno považovat' v slovenskom nábožensko-kultúrnom prostredí azda za jedno z najznámejších a najfrekventovanejších. Najprv sa zameriame na jeho používanie v náboženskej literatúre, konkrétne vo vydaniach Jednotného katolíckeho spevníka, a to $\mathrm{v}$ textoch piesní $\mathrm{k}$ týmto svätcom a v modlitbe Litánií $k$ svätým ${ }^{5}$, následne budeme frekvenciu používania singulárových aj plurálových variantov prívlastku svätý analyzovat' v textoch Slovenského národného korpusu (dalej ako SNK). Kým pri analýze uvedeného spojenia v litániách sekundárne poukážeme aj na d’alšie analogické príklady spojenia prívlastku svätýs viacerými menami svätých (kedže výpočet svätých je tu konečný), pri analýze frekvencie používania singulárových a plurálových variantov tohto prívlastku v SNK sa z dôvodu vel'kého počtu takýchto spojení obmedzíme len na spojenie svätý Cyril a Metod (vrátane všetkých pádových tvarov), na ktorom budeme pars pro toto demonštrovat tendencie v používaní singulárových, resp. plurálových tvarov prívlastku svätý pred viacerými menami, pretože nepredpokladáme, že by v prípade spojení tohto prívlastku s menami iných svätých bola situácia odlišná.

\subsection{Spojenia svätý Cyril a Metod - svätí Cyril a Metod vo vydaniach Jednotného katolíckeho spevníka}

Kedže Jednotný katolícky spevník, ako sa uvádza v predhovore k 79. vydaniu (2018), patrí ku klúčovým publikáciám duchovného života na Slovensku a spomedzi katolíckych modlitebných a spevníkových publikácií vydaných na Slovensku ho považujeme za dielo kardinálneho významu, rozhodli sme sa analyzovat používanie spojenia svätý Cyril a Metod práve v jednotlivých

5 Podla informácie uvedenej v 79. vydaní JKS (2018) vznikli tieto litánie za čias pápeža Sergia I. (687 - 701). Druhým vatikánskym koncilom boli upravené. V jednotlivých vydaniach $J K S$ sa uvádzali rôzne podoby názvu týchto litánií: Litánie ku všetkým svätým, Litánie o všetkých svätých a napokon Litánie $k$ svätým. Práve názov Litánie $k$ svätým považujeme za najvhodnejší, kedže vzývania v tejto modlitbe sú adresované svätým, preto tu za náležitú považujeme predložku $k$. Z názvu sa tiež už vynecháva prívlastok $v$ šstkým/ všetkých, pretože tieto litánie neobsahujú mená všetkých, ale len vybraných svätých, hoci čast vzývaní k jednotlivým svätým je zakončená spoločnou invokáciou Všetci Boží svätí a sväté (porov. napr. 62. vydanie JKS (1992), 74. vydanie JKS (2012a), 79. vydanie JKS (2018)). Pri analýze konkrétneho vydania JKS rešpektujeme podobu názvu uvedenú v konkrétnom vydaní. 
vydaniach $J K S^{6}$. Ako sa dalej v predhovore k uvedenému vydaniu píše, $J K S$ vo vel'kej miere prispel aj k zjednocovaniu slovenčiny (JKS 2018). O jeho vydávanie sa od začiatku stará Spolok svätého Vojtecha. Pri analýze používania prívlastku svätý pred menami Cyril a Metod budeme vychádzat’ z piesní adresovaných sv. Cyrilovi a Metodovi, ako aj z modlitby Litánií k svätým.

Hoci v 1. vydaní JKS (1937) Litánie ku všetkým svätým v slovenskom jazyku nie sú (iba latinské ${ }^{7}$, nachádza sa tu niekol'ko piesní k sv. Cyrilovi a Metodovi ${ }^{8}$. Ide o piesne č. 430 Budte zvelebení, 431 Duša krestanská, zvelebuj Boha, 432 Oslavujme hviezdy jasné a 433 Ó, krásne svetlá otčiny. Pod názvom každej z týchto piesní je špecifikované, že ide o pieseň k uvedeným svätcom, pričom v týchto určeniach sa skrátený prívlastok $s v$. nachádza pred oboma menami: $K s v$. Cyrilovi a sv. Metodovi $i^{9}$. Osobitne sv. Metodovi je ešte venovaná pieseň č. 434 Tisíc rokov preletelo (s podnadpisom $K s v$. Metodovi). Zaujímavé však je, že práve v piesni č. 430 Budte zvelebení sa uvádza plurálový tvar prívlastku pri asyndetickom (bezspojkovom) spojení mien Cyrila a Metoda: svätí Cyril, Metod. V novších vydaniach JKS ale nachádzame podobu svätý Cyril, Metod (porov. pozn. 20). V dalších uvedených piesňach publikovaných v 1 . vydaní JKS (1937) už evidujeme singulárové podoby prívlastku svätý: v piesni č. 431 Duša krestanská, zvelebuj Boha sa uvádza spojenie Svätý Cyril, svätý Metod (viac k tomu porov. aj v pozn. 16). V piesni č. 432 Oslavujme hviezdy jasné sa nachádza eliptické spojenie svätý Cyril i Metod. Singulárové a plurálové podoby prívlastku svätý pred menami Cyril a Metod v týchto piesňach sa používajú rovnako aj v 62. vydaní JKS (1992). Možno teda zhodnotit, že s výnimkou analyzovanej piesne č. 430, ktorá sa v starších vydaniach JKS (porov. napr. 1. vydanie (1937) a 62. vydanie (1992)) uvádza s plurálovou podobou prívlastku svätý, t. j. svätí, sa ostatné analyzované piesne aj v novších vydaniach JKS (porov. napr. 74 . vydanie (2012a), 79. vydanie (2018)) vyskytujú nemenne, pokial ide o používanie prívlastku svätý v singulárovej podobe.

V súvislosti s uvádzaním spojenia Svätý Cyril a Metod v litániách treba uviesté, že ani v skorších vydaniach JKS (napr. 11. vydanie (1944), 17. vydanie (1950)), v ktorých sa už Litánie o všetkých svätých uvádza po slovensky, sa ešte svätý Cyril a Metod v tejto modlitbe neuvádzajú. No nachádzajú sa tu iné analogické prípady spojenia prívlastku svätý s viacerými menami: Svätý Fabián a Šebastián, Svätý Ján a Pavol, Svätý Kozma a Damián, Svätý Gerváz a Protáz. Pokial sa však $\mathrm{v}$ plurálovom tvare nachádza už prvý člen spojenia mien, prívlastok svätý je v plurálovom tvare, napr.: Všetci svätí anjeli a archanjeli, Všetky sväté panny a vdovy. Prívlastok svätý tu dokonca nachádzame aj v substantivizovanej funkcii, ked' plurálový tvar rozlišuje i menný rod: Všetci svätí a sväté Božie. Tendenciu používat prívlastok svätý v singulárovom tvare, ak sa prvé meno viacnásobného člena nachádza v singulári, teda dokazujú už velmi skoré vydania $J K S$, pričom, ako na to

6 Naším cielom nie je chronologicky zachytił všetky zmeny, ktorými Jednotný katolícky spevník prešiel od začiatku svojho vydávania až po súčasnost', pokial ide o použivanie spojenia svätý pred menami Cyril a Metod a iných analogických spojení. Na porovnanie a naznačenie vývinu v tejto oblasti výberovo pracujeme aj so staršími vydaniami JKS, no primárne sa zameriavame najmä na súčasný stav v používaní analyzovaných spojení v tomto modlitebnom a spevníkovom diele.

7 V Obsahu spevníka je však napriek tomu názov litánií uvedený po slovensky ako Litánie ku všetkým svätým (latinské). Treba ale uviest', že ani v latinskom texte litánií sa ešte sv. Cyril a Metod neuvádzajú.

8 Okrem uvedených piesní priamo adresovaných svätému Cyrilovi a Metodovi sa spojenie svätý Cyril a Metod (a jeho rôzne obmeny) môže nachádzat aj v iných piesňach, napr. prostredníctvom vyhladávania v SNK sme spojenie svätý Cyril, svätý Metod zaznamenali aj v mariánskej piesni č. 396 Pozdravujeme ta (viac $\mathrm{k}$ tomu porov. v pozn. 16).

9 V novších vydaniach JKS (napr. 74. vydanie (2012a), 79. vydanie (2018)) sa určenie $K$ sv. Cyrilovi a sv. Metodovi so skratkou sv. pred oboma menami nachádza spoločne nad piesňami č. 430 - 433, podobne sa takéto spoločné určenie nachádza napríklad aj v 62. vydaní JKS (1992), ale prívlastok sv. je uvedený iba pred menom Cyril. 
poukážeme, táto tendencia sa uplatňuje nemenne až po súčasné vydania. Pridaním spojenia Svätý Cyril a Metod so singulárovým tvarom prívlastku svätý do modlitby litánií sa teda v tejto tradícii len pokračuje.

V 41. vydaní JKS (1971) nachádzame v Litániách o všetkých svätých okrem spojenia Svätý Cyril a Metod a predchádzajúcich uvedených spojení mien svätých aj dalších svätcov zásadného významu v slovenskom prostredí - Svätý Andrej a Benedikt $t^{10}$.

Rovnako aj v novších vydaniach JKS (napr. 74. vydanie (2012a), 79. vydanie (2018)) sa $\mathrm{v}$ Litániách $k$ svätým prívlastok svätý pri viacerých menách používa $\mathrm{v}$ singulárovej podobe (ak je prvé meno v singulárovom tvare), dokonca tu nájdeme i spojenia s viac ako dvomi menami: Svätý Michal, Gabriel a Rafael ${ }^{11}$. Nachádzame tu aj spoločné uvedenie už spomínaných dvoch svätíc: Svätá Perpetua a Felicita. Prívlastok svätý v substantivizovanej funkcii rozlišujúci plurálovými tvarmi menný rod sa v novších vydaniach JKS (napr. 74. vydanie (2012a), 79. vydanie (2018), ale aj 62. vydanie (1992)) uvádza v podobe Všetci Boží svätí a sväté.

Analýza litánií v daných vydaniach $J K S$ z rôznych období dokazuje, že hoci sa počet svätých $\mathrm{v}$ tejto modlitbe postupne zvyšuje, analyzované tendencie $\mathrm{v}$ používaní prívlastku svätý pri spoločnom uvádzaní viacerých mien sú nemenné, čo - okrem dobre ustálených gramatických tendencií - podla nášho názoru dokazuje aj význam tradície v závažných náboženských textoch, ako o tom hovorí citovaný I. Masár (1991, 317).

\subsection{Spojenia svätý Cyril a Metod - svätí Cyril a Metod v textoch Slovenského národného korpusu}

Kedže v slovenskom nábožensko-kultúrnom prostredí sú svätý Cyril a Metod vel’mi známi, rozšírení a oblúbení svätci a je po nich pomenovaných aj vela inštitúcií, združení, spolkov a pod., rozhodli sme sa frekvenčne porovnat používanie singulárovej a plurálovej formy prívlastku svätý pri menách Cyril a Metod na základe výskytov týchto spojení v textoch SNK. Do analýzy sme zahrnuli bežné výskyty v lubovol’nom texte, ale aj výskyty v názvoch inštitúcií. Analýzu sme realizovali v hlavnom korpuse prim-9.0-public-sane (dalej ako PRIM9) ${ }^{12}$ a na porovnanie aj v špecializovanom korpuse náboženských textov blf-2.0 (dalej ako BLF2) ${ }^{13}$. I ked' hlavný korpus PRIM9 tiež obsahuje texty aj z náboženskej oblasti (špecializované korpusy sa tvoria z hlavných korpusov), považujeme za podnetné porovnat výskyty v hlavnom korpuse, ktorý okrem textov z náboženskej

10 V novších vydaniach JKS (napr. 74. vydanie (2012a), 79. vydanie (2018), ale aj 62. vydanie (1992)) sa toto spojenie uvádza ako Svätý Andrej Svorad a Benedikt, teda k reholnému menu prvého svätca sa pridáva aj jeho krstné (občianske) meno.

11 Kým v skorších vydaniach JKS (napr. 11. vydanie (1944), 17. vydanie (1950), 41. vydanie (1971)) sa všetky tri mená uvádzali osobitne, t. j. Svätý Michal, Svätý Gabriel, Svätý Rafael, pričom po každej invokácii nasledovalo zvolanie oroduj za nás, $\mathrm{v}$ prípade ich spoločného uvedenia v novších vydaniach JKS (napr. 74. vydanie (2012a), 79. vydanie (2018), ale aj 62. vydanie (1992)) nasleduje len jedno zvolanie v plurálovom tvare orodujte za nás.

12 Hlavný korpus textov prim-9.0-public-sane obsahuje 1620900802 tokenov, 1256679127 slov (73,69 \% publicistické; $16,21 \%$ umelecké; 9,23\% odborné; 0,87 \% iné texty) - bez textov s nesprávnou diakritikou a z oblastí mimo Slovenska (Štruktúra korpusu prim-9.0 2021). Treba uviest', že ide o korpus písaných textov (Verejne prístupné korpusy SNK 2021). Token je základná jednotka korpusu, ide o znak alebo súbor znakov formálne oddelených od iného znaku alebo súboru znakov napr. medzerou. Môže to byt slovo, tvar slova, interpunkčné znamienko atd. (Šimková 2017, 148).

13 Špecializovaný korpus textov z tematickej oblasti viera a nadprirodzeno blf-2.0 bol sprístupnený 18. 12. 2014 v rozsahu takmer 66 miliónov tokenov (Korpus náboženských textov 2021), takisto ide o korpus písaných textov (Verejne prístupné korpusy SNK 2021). 
tematickej oblasti obsahuje aj texty z iných oblastí, s výskytmi v korpuse náboženských textov. ${ }^{14}$ Samozrejme, analyzovali sme len používanie prívlastku v neskrátenej forme, t. j. svätý/svätí (v jednotlivých pádových tvaroch). ${ }^{15}$ Zo spojení s neskráteným prívlastkom svätý sme sa zamerali iba na eliptické spojenia svätý Cyril a Metod, kedže pri uvedení úplného spojenia svätý Cyril a svätý Metod ${ }^{16}$ prichádza do úvahy použitie prívlastku výlučne v singulárovom tvare.

Najprv sme sa zamerali na analýzu používania prívlastku svätý v spojení s menami Cyril a Metod v jednotlivých singulárových i plurálových pádových tvaroch v korpuse PRIM9. Analýza absolútnej frekvencie (počtu výskytov) singulárových a plurálových tvarov atribútu svätý ukazuje - v porovnaní s používaním singulárových tvarov tohto atribútu v žánroch piesní a litánií na výraznú preferenciu plurálových tvarov tohto prívlastku. Podla výskytov v korpuse PRIM9 sa plurálové podoby používajú zhruba trikrát častejšie ako singulárové tvary (porov. celkový počet výskytov singulárových a plurálových tvarov v tabul'ke 1).

14 Potrebné je však uviest', že špecializovaný korpus náboženských textov BLF2 bol vytvorený zo staršej verzie hlavného korpusu, nie $\mathrm{z}$ verzie PRIM9, ako to vyplýva z dátumu sprístupnenia hlavného korpusu písaných textov prim-9.0 - 22. 7.2020 (Štruktúra Slovenského národného korpusu 2021). Preto niektoré výskyty aj v textoch z náboženskej oblasti, ktoré sme zaznamenali v korpuse PRIM9, sme nezaznamenali v korpuse BLF2.

15 Na porovnanie ale treba uviest', že v oboch korpusoch sa pred menami Cyril a Metod používa najmä skratka $s v$., ako to dokazuje početnost’ výskytov nasledovných spojení: sv. Cyril a Metod (vrátane všetkých pádových tvarov) - 12872 výskytov (i.p.m.: 7,94; ARF: 3 186,55) v PRIM9, 4226 výskytov (i.p.m.: 64,11; ARF: 1 276,10) v BLF2; sv. Cyril a sv. Metod (vrátane všetkých pádových tvarov) - 721 výskytov (i.p.m.: 0,44; ARF: 224,93) v PRIM9, 212 výskytov (i.p.m.: 3,22; ARF: 71,56) v BLF2. Iné typy spojení oboch mien (napr. pomocou spojok $i$, aj či bezspojkové spojenie pomocou čiarky) vzhladom na minimálne počty výskytov a s ohladom na zameranie tohto príspevku neuvádzame. Vysvetlenie štatistických ukazovatelov i.p.m. a ARF porov. v pozn. 17.

16 Spojenie svätý Cyril a svätý Metod sa v korpuse PRIM9 nachádza celkovo 95-krát (i.p.m.: 0,06; ARF: 40,56), v korpuse náboženských textov BLF2 sme zaznamenali 38 výskytov (i.p.m.: 0,58; ARF: 16,39). Ide o výskyty vo všetkých singulárových pádových tvaroch (vysvetlenie štatistických ukazovatelov i.p.m. a ARF porov. v pozn. 17). Motiváciou uvedenia prívlastku svätý pred oboma menami môže byt’ snaha o zdôraznenie platnosti atribútu pre obe mená, resp. podčiarknutie ich rovnocennosti. V tejto súvislosti uvedieme aj na názov výberovej antológie Svätý Cyril a svätý Metod v slovenskej literatúre, ktorú zostavili Peter Liba a Silvia Lauková (2012). Podobu svätý Cyril, svätý Metod (asyndetické spojenie) hodnotíme ako vel’mi zriedkavú (v PRIM9 len 5 výskytov, v BLF2 iba 1 výskyt), nachádza sa však v dvoch piesňach z JKS - porov. pieseň č. 396 Pozdravujeme ta: 1. Pozdravujeme tá,-patrónka Slovenska, - Sedembolestná Matička, - našej zeme si patrónka, - naša dobrá Matka! - 2. K tebe nás priviedli - apoštoli viery - svätý Cyril, svätý Metod, - ked'pohanstva t’ažkých nehôd - zbavili nás vtedy a pieseň č. 431 Duša krest’anská, zvelebuj Boha: - Svätý Cyril, svätý Metod, - lud krestanský ctí váš príchod [...]. V korpuse PRIM9 je zaradené 74. vydanie JKS (2012b), z ktorého citované príklady piesní pochádzajú, v rovnakej gramatickej forme sa však tieto spojenia v uvedených piesňach nachádzajú aj v 79. vydaní JKS (2018). V tomto prípade pri uvádzaní prívlastku svätý pred oboma menami a v asyndetickom spojení zohráva úlohu najmä rytmický činitel.' 
Tabul'ka 1: Analýza frekvencie spojení svätý/svätí Cyril a Metod v jednotlivých pádových tvaroch v korpuse PRIM9 ${ }^{17}$

\begin{tabular}{|c|c|c|c|c|c|c|}
\hline & $\begin{array}{l}\text { Singulárové } \\
\text { tvary }\end{array}$ & $\begin{array}{l}\text { Absolútna } \\
\text { frekvencia } \\
\text { (počet } \\
\text { výskytov) }\end{array}$ & i.p.m./ARF & $\begin{array}{l}\text { Plurálové } \\
\text { tvary }\end{array}$ & $\begin{array}{l}\text { Absolútna } \\
\text { frekvencia } \\
\text { (počet } \\
\text { výskytov) }\end{array}$ & i.p.m./ARF \\
\hline $\mathrm{N}$ & $\begin{array}{l}\text { svätý Cyril } \\
\text { a Metod }\end{array}$ & 159 & $0,10 / 38,57$ & $\begin{array}{l}\text { svätí Cyril } \\
\text { a Metod }\end{array}$ & 693 & $0,43 / 110,19$ \\
\hline G/A & $\begin{array}{l}\text { svätého } \\
\text { Cyrila } \\
\text { a Metoda }\end{array}$ & 805 & $0,50 / 270,43$ & $\begin{array}{l}\text { svätých } \\
\text { Cyrila } \\
\text { a Metoda }\end{array}$ & 2419 & $1,49 / 345,22$ \\
\hline $\mathrm{D}$ & $\begin{array}{l}\text { svätému } \\
\text { Cyrilovi } \\
\text { a Metodovi }\end{array}$ & 52 & $0,03 / 14,98$ & $\begin{array}{l}\text { svätým } \\
\text { Cyrilovi } \\
\text { a Metodovi } \\
\end{array}$ & 107 & $0,07 / 25,45$ \\
\hline $\mathrm{L}$ & $\begin{array}{l}\text { (o) svätom } \\
\text { Cyrilovi } \\
\text { a Metodovi }\end{array}$ & 25 & $0,02 / 11,68$ & $\begin{array}{l}\text { (o) svätých } \\
\text { Cyrilovi } \\
\text { a Metodovi }\end{array}$ & 40 & $0,02 / 8,95$ \\
\hline I & $\begin{array}{l}\text { svätým } \\
\text { Cyrilom } \\
\text { a Metodom }\end{array}$ & 14 & $0,01 / 6,75$ & $\begin{array}{l}\text { svätými } \\
\text { Cyrilom } \\
\text { a Metodom }\end{array}$ & 15 & $0,01 / 6,79$ \\
\hline $\begin{array}{l}\text { Celkový } \\
\text { počet } \\
\text { výskytov }\end{array}$ & & 1055 & & & 3274 & \\
\hline
\end{tabular}

Frekvenčné údaje v tabulke 1 poukazujú ešte na jednu tendenciu, a to na podstatne vyšší počet výskytov singulárových i plurálových tvarov v G, resp. A. Vzhl’adom na to, že pri životných substantívach sú tvary G a A sg. i pl. formálne totožné, prezentujeme počet výskytov v oboch pádoch spoločne, no na základe analýzy výskytov daných tvarov môžeme vyslovit hypotézu o výraznej dominancii genitívnych tvarov nad akuzatívnymi ${ }^{18}$, ktorú by mohol nepriamo potvrdzovat aj

17 Výskyty analyzovaného spojenia $\mathrm{v}$ jednotlivých pádových tvaroch sme vyhladávali pomocou regulárnych výrazov. Vysvetlenie jednotlivých štatistických ukazovatelov uvádzame podla Šimkovej $(2017,139)$ :

- absolútna frekvencia (počet výskytov) - absolútny výskyt jazykového prostriedku vo zvolenom rozsahu textu alebo $\mathrm{v}$ súbore textov, $\mathrm{v}$ našom prípade vo zvolenom korpuse;

- i.p.m. (instances per million) - frekvencia jazykového prostriedku v danom korpuse prepočítaná ako priemerný výskyt daného prostriedku vo fiktívnom korpuse toho istého zloženia s rozsahom 1 mil. tokenov; vdaka tejto hodnote je možné porovnávat výskyt hladaného prvku v korpusoch rôzneho rozsahu;

- ARF (priemerná redukovaná frekvencia) - frekvencia prepočítaná podla disperzie (rozloženia) jazykových prostriedkov vo všetkých textoch v korpuse; koriguje sa frekvenčné poradie jazykových jednotiek $\mathrm{s}$ vy̌ším absolútnym výskytom, no iba $\mathrm{v}$ jednom texte či $\mathrm{v}$ malom počte textov $\mathrm{v}$ porovnaní $\mathrm{s}$ jazykovými prostriedkami používanými v mnohých textoch.

18 Z celkového počtu 805 singulárových tvarov svätého Cyrila a Metoda v G i A sme ako tvary v A prostredníctvom vyhladávania pomocou morfologických značiek identifikovali iba 30 výskytov. Z celkového počtu 2419 plurálových tvarov v G i A sme ako tvary v A identifikovali 109 výskytov. Musíme však upozornit na obmedzenú spolahlivost automatizovanej anotácie morfologickými značkami v korpuse PRIM9. Vyhladané akuzatívne tvary sme ručne skontrolovali a z výsledkov vyhladávania 
výskyt genitívnych tvarov v názvoch rôznych inštitúcií, združení či spolkov. V oficiálnych názvoch sa pred spojením mien Cyril a Metod obyčajne používa iba skratka sv., ktorá sa pri vyslovovaní daného názvu alebo jeho písomnom uvádzaní používa v singulárovom i plurálovom tvare, takže vznikajú variantné podoby názvov daných inštitúcií, združení či spolkov, ako to dokazujú príklady používania názvov nasledovných inštitúcií či spolku z korpusu PRIM9 (názvy uvádzame v nominatívnom tvare): Slovenský ústav svätého/svätých Cyrila a Metoda v Ríme, Univerzita svätého/svätých Cyrila a Metoda v Trnave, Cirkevná základná škola svätého/svätých Cyrila a Metoda v Snine, Gymnázium svätého/svätých Cyrila a Metoda v Nitre, Spolok svätého/svätých Cyrila a Metoda atd.

Singulárové pádové tvary prívlastku svätý pred menami Cyril a Metod sa v korpuse PRIM9 nachádzali napríklad v týchto kontextoch:

Svätý Cyril a Metod sú od roku 1980 spolupatrónmi Európy (TK KBS 2010). - Na jar 2012 osadili pri chráme sochy svätého Cyrila a Metoda (MY Žilinské noviny 2015). Novozámčania si uctili svätého Cyrila a Metoda (MY Naše novosti 2017). - V roku 1853 vtedajší banskobystrický biskup Mons. Štefan Moyses zaviedol vo svojej diecéze pravidelné slávenie úcty $k$ svätému Cyrilovi a Metodovi (TK KBS 2011). - Areál bývalých kasární pod Zoborom sa má stat' miestom nakrúcania dlhometrážneho filmu o svätom Cyrilovi a Metodovi (Hospodárske noviny 2010). - V liste tlmočí prosbu Jána Pavla II., aby posolstvo pokoja a vernosti Kristovi a Evanjeliu prinášalo bohaté ovocie na hojný úžitok všetkých, $v$ smere cesty naznačenej svätým Cyrilom a Metodom, s ich pomocou a pod ich ochranou (SME 1995).

Plurálové pádové tvary atribútu svätý pred menami Cyril a Metod sa v korpuse PRIM9 nachádzali napríklad v týchto kontextoch:

Duchovné dary, ktoré nám svätí Cyril a Metod s Božou pomocou sprostredkovali, prinášajú dodnes ovocie (Katolícke noviny2013). - Mala by to byt duchovná príprava na jubileum začiatku misie svätých Cyrila a Metoda u nás (Blumentál 2011). - Európania si dnes spomínajú na svätých Cyrila a Metoda, spolupatrónov Európy (TK KBS 2006). - Celoslovenská pút k svätým Cyrilovi a Metodovi (Katolícke noviny 2010). - V Nitre budú nakrúcat'vel'kofilm o svätých Cyrilovi a Metodovi (TK KBS 2009). - Gorazd je autorom apoštolského, pedagogického, diplomatického a štátnického diela, samozrejme, so svätými Cyrilom a Metodom a d’alšími vtedajšími osobnostami (MY Liptovské noviny 2011).

S cielom porovnania sme sa rozhodli zrealizovat frekvenčnú analýzu používania singulárových a plurálových tvarov prívlastku svätý pred menami Cyril a Metod aj v špecializovanom korpuse náboženských textov BLF2. Vzhladom na to, že rozsah tohto korpusu je menší (porov. pozn. 13), je prirodzené očakávat nižšie počty výskytov vyhladávaných spojení. Ako sme uviedli, kedže tento korpus vznikol zo staršej verzie hlavného korpusu (porov. pozn. 14), mnohé výskyty vyhladaných tvarov v daných kontextoch sú totožné v oboch korpusoch. Preto z korpusu BLF2 už príklady

sme vylúčili genitívne tvary, ktoré SNK identifikoval ako akuzatívne. Mohlo sa však stat', že medzi niektoré genitívne tvary systém zaradil aj v skutočnosti akuzatívne tvary (preto tieto tvary vo výsledkoch akuzatívnych tvarov mohli absentovat'), genitívne tvary sme vzhladom na vysoký počet výskytov ručne nekontrolovali. Preto je potrebné uvedené pomery medzi genitívnymi a akuzatívnymi tvarmi chápat iba orientačne, predsa však výrazný rozdiel medzi oboma pádmi v prospech genitívnych tvarov považujeme za signifikantný. 
kontextov, v ktorých sa spojenia svätý/svätí Cyril a Metod nachádzali, neuvádzame. Bude však zaujímavé sledovat', či korpus obsahujúci iba texty z náboženskej tematickej oblasti preukáže rovnaké tendencie v používaní skúmaných spojení ako hlavný korpus PRIM9, ktorý okrem textov náboženského charakteru obsahuje aj texty z iných oblastí (porov. pozn. 12).

Tabulka 2: Analýza frekvencie spojení svätý/svätí Cyril a Metodv jednotlivých pádových tvaroch v korpuse BLF2

\begin{tabular}{|c|c|c|c|c|c|c|}
\hline & $\begin{array}{l}\text { Singulárové } \\
\text { tvary }\end{array}$ & $\begin{array}{l}\text { Absolútna } \\
\text { frekvencia } \\
\text { (počet } \\
\text { výskytov) } \\
\end{array}$ & i.p.m./ARF & $\begin{array}{l}\text { Plurálové } \\
\text { tvary }\end{array}$ & Výskyty & i.p.m./ARF \\
\hline $\mathrm{N}$ & $\begin{array}{l}\text { svätý Cyril } \\
\text { a Metod }\end{array}$ & 95 & $1,44 / 24,55$ & $\begin{array}{l}\text { svätí Cyril } \\
\text { a Metod }\end{array}$ & 340 & $5,16 / 91,04$ \\
\hline $\mathrm{G} / \mathrm{A}$ & $\begin{array}{l}\text { svätého } \\
\text { Cyrila } \\
\text { a Metoda }\end{array}$ & 359 & $5,45 / 116,20$ & $\begin{array}{l}\text { svätých } \\
\text { Cyrila } \\
\text { a Metoda }\end{array}$ & 1543 & $23,41 / 440,24$ \\
\hline $\mathrm{D}$ & $\begin{array}{l}\text { svätému } \\
\text { Cyrilovi } \\
\text { a Metodovi }\end{array}$ & 41 & $0,62 / 12,63$ & $\begin{array}{l}\text { svätým } \\
\text { Cyrilovi } \\
\text { a Metodovi }\end{array}$ & 71 & $1,08 / 23,73$ \\
\hline $\mathrm{L}$ & $\begin{array}{l}\text { (o) svätom } \\
\text { Cyrilovi } \\
\text { a Metodovi }\end{array}$ & 11 & $0,17 / 3,91$ & $\begin{array}{l}\text { (o)svätých } \\
\text { Cyrilovi } \\
\text { a Metodovi }\end{array}$ & 29 & $0,44 / 11,10$ \\
\hline I & $\begin{array}{l}\text { svätým } \\
\text { Cyrilom } \\
\text { a Metodom }\end{array}$ & 8 & $0,12 / 3,67$ & $\begin{array}{l}\text { svätými } \\
\text { Cyrilom } \\
\text { a Metodom }\end{array}$ & 11 & $0,17 / 5,62$ \\
\hline $\begin{array}{l}\text { Celkový } \\
\text { počet } \\
\text { výskytov }\end{array}$ & & 514 & & & 1994 & \\
\hline
\end{tabular}

Z porovnania počtov výskytov singulárových i plurálových tvarov prívlastku svätý pred menami Cyril a Metod v tabulke 2 vyplýva, že i v textoch z náboženskej tematickej oblasti sa prejavuje rovnaká tendencia preferovania plurálových podôb prívlastku svätý, dokonca je tu pomer výskytu plurálových tvarov v porovnaní so singulárovými tvarmi ešte vyšší ako v korpuse PRIM9. Ako najpočetnejšie, resp. najčastejšie používané, sa opät ukazujú formálne zhodné tvary G/A, $\mathrm{z}$ nich najmä genitívne tvary. ${ }^{19}$

Ďalej môžeme skonštatovat, že tabul'ka 2 v porovnaní s tabulkou 1 obsahuje podstatne vyššie hodnoty i.p.m. vyjadrujúce prepočítaný priemerný výskyt prvku v korpuse totožného zloženia s hypotetickým rozsahom 1 mil. tokenov (podrobnejšie vysvetlenie štatistického ukazovatela

19 Na vyhladanie akuzatívnych tvarov sme použili rovnaký postup ako v korpuse PRIM9 (porov. pozn. 18). Opät upozorňujeme na potrebu chápat pomer genitívnych a akuzatívnych tvarov iba orientačne (napriek ručnej kontrole vyhladaných akuzatívnych tvarov tu treba brat do úvahy aj fakt, že systém medzi formálne zhodnými tvarmi v $\mathrm{G}$ a A nevyhladal všetky tvary v A, a teda tieto tvary mohli vo výsledkoch vyhladaných akuzatívnych tvarov absentovat): z celkového počtu 359 singulárových tvarov svätého Cyrila a Metoda v G i A sme ako tvary v A identifikovali 19 výskytov. Z celkového počtu 1543 plurálových tvarov svätých Cyrila a Metoda v G i A sme ako tvary v A identifikovali 68 výskytov. 
i.p.m. porov. v pozn. 17 a termínu token v pozn. 12); tieto hodnoty dokazujú vyššiu frekvenciu analyzovaných spojení svätý/svätí Cyril a Metod (vrátane všetkých pádových tvarov) v korpuse náboženských textov BLF2 v porovnaní s korpusom PRIM9.

V korpusoch PRIM9 i BLF2 sme zaznamenali aj asyndetické (bezspojkové) spojenie mien Cyril a Metod, vtedy sa však tieto mená takmer absolútne nachádzali vo viacčlenných syntagmách (obyčajne troch) ${ }^{20}$, napr.: súsošie svätých Cyrila, Metoda a Gorazda (TK KBS 2012). V tomto type spojení tiež prevažovali najmä plurálové tvary prívlastku svätý. ${ }^{21}$ Spojenie mien Cyril a Metod inými spojkami ( $i$ a aj) hodnotíme ako velmi ojedinelé. ${ }^{22}$ Napokon sme v korpusoch zaznamenali i spojenia svätýl svätí Konštantín a Metod ${ }^{23}$, ich počet výskytov bol však relatívne nízky, preto sme im nevenovali zvláštnu pozornost'; ešte zriedkavejšie bolo spojenie svätý/svätí Konštantín Cyril a Metod, resp. svätý/svätí Konštantín-Cyril a Metod (zápis mena Konštantín-Cyril so spojovníkom) ${ }^{24}$, no i frekvencia

${ }_{20}$ Dvojčlenné asyndetické spojenie svätý Cyril, Metod sme zaznamenali iba v korpuse PRIM9, a to v spomínanej piesni č. 430 Budte zvelebení z JKS: Budte zvelebení - a večne slávení, - svätý Cyril, Metod, - bratia svätí [...]. Okrem 74. vydania JKS (2012b), ktoré je evidované v PRIM9 a z ktorého citovaný príklad pochádza, takúto formu uvedeného spojenia potvrdzuje aj 79. vydanie JKS (2018). Ako sme však uviedli, v 1. vydaní JKS (1937) i v 62. vydaní JKS (1992) nachádzame v tejto piesni podobu svätí Cyril, Metod.

Druhý výskyt $\mathrm{v}$ korpuse PRIM9 pochádzal z tlače: Nápis, ktorý sa na zvone nachádza, je vlastne modlitbou: „Svätý Cyrile, Metode, proste matku Máriu, by nám vždy bránila našu vlast', Slovenskú krajinu“ (MY Hornonitrianske noviny 2013). V druhom uvedenom príklade dokonca nachádzame mená Cyril a Metod $\mathrm{v}$ archaických tvaroch vokatívu, ktoré môžu byt príznačné pre niektoré (najmä staršie) modlitby.

${ }^{21} \mathrm{Z}$ celkového počtu 45 výskytov (i.p.m.: 0,03; ARF: 8,83) trojčlenných spojení v korpuse PRIM9 sa singulárový tvar atribútu svätý nachádzal len 6-krát. V záujme objektívnosti výsledkov však musíme uviest', že z celkového počtu výskytov až 41-krát išlo práve o spojenie svätý Cyril, Metod a Gorazd (s prívlastkom svätý $\mathrm{v}$ príslušnom singulárovom či plurálovom tvare). Vo vyhladaných textoch sa písalo o plánovanom súsoší svätých Cyrila, Metoda a Gorazda v Bratislave.

V korpuse BLF2 sa trojčlenné spojenia nachádzali 34-krát (i.p.m.: 0,52; ARF: 7,57), z toho až 32-krát išlo práve o spojenie svätý Cyril, Metod a Gorazd (v rovnakom významovom kontexte ako v korpuse PRIM9, t. j. informovalo sa tu o plánovanom súsoší svätých Cyrila, Metoda a Gorazda v Bratislave), v dvoch prípadoch išlo o spojenie s menom sv. Benedikta: Tento mesiac slávime už tretí sviatok spolupatróna Európy. Po svätých Cyrilovi, Metodovi a Benediktovi je to dnes svätá Brigita (Slovo medzi nami 2008). Z uvedených 34 výskytov sme singulárový tvar prívlastku svätý identifikovali iba v 4 prípadoch.

Vzhladom na uvedené skutočnosti nie je možné z týchto výskytov robit závery, že by sa pri troja viacčlenných spojeniach mien výraznejšie preferovala plurálová podoba prívlastku svätý v porovnaní s dvojčlennými syntagmami. Kedže však aj pri dvojčlenných spojeniach frekvenčná analýza dokázala výrazné preferovanie plurálových tvarov atribútu svätý, aj na základe prezentovaných výsledkov sa dá predpokladat', že ani pri troj- a viacčlenných spojeniach to nie je inak, resp. možno formulovat' hypotézu, že počet mien, ktoré sa v koordinatívnej syntagme spájajú, nie je rozhodujúci a už pri dvojčlenných spojeniach mien tu prevláda tendencia použit prívlastok svätý v plurálovom tvare, pričom pri viacčlenných spojeniach táto tendencia pokračuje.

22 Spojenia mien Cyril a Metod spojkou $i$ sme zaznamenali iba v korpuse PRIM9, a to v počte 4 výskyty, pričom vo všetkých prípadoch mal prívlastok svätý singulárový tvar. Potrebné je však uviest', že z týchto výskytov až dva boli práve zo spomínanej piesne č. 432 Oslavujme hviezdy jasné, ktorá bola publikovaná v 74. vydaní JKS (2012b), evidovanom aj v korpuse PRIM9. Spojenie so spojkou aj sme zaznamenali v korpuse PRIM9 i BLF2 iba jedno (išlo však o rovnaký výskyt v totožnom texte nachádzajúcom sa $\mathrm{v}$ oboch korpusoch), pričom aj v tomto prípade sa prívlastok svätý nachádzal v singulári.

${ }^{23}$ Z celkového počtu 44 výskytov (i.p.m.: 0,03; ARF: 13,75) spojení svätý/svätí Konštantín a Metod (v rôznych pádových tvaroch) v korpuse PRIM9 boli len 4 výskyty so singulárovým tvarom prívlastku svätý. Z celkového počtu 16 výskytov (i.p.m.: 0,24; ARF: 4,79) týchto spojení v korpuse BLF2 sme singulárový tvar prívlastku svätý identifikovali iba v 2 spojeniach.

${ }^{24}$ Z 9 výskytov spojenia svätý/svätí Konštantín Cyril a Metod sme v korpuse PRIM9 singulárový tvar prívlastku svätý zaznamenali iba 1-krát. V spojení svätý/svätí Konštantín-Cyril a Metod sme v rovnakom 
uvedených zriedkavých spojení v oboch korpusoch tiež potvrdzuje tendenciu používat prívlastok svätý pred spojeniami viacerých mien v koordinatívnej syntagme v plurálovom tvare. Podobne ako pred menami Cyril a Metod aj v spojeniach s d’alšími variantmi mena svätého Cyrila sme v analyzovaných spojeniach zaznamenali uvedenia prívlastku svätý pred oboma menami, t. j. pred variantom mena svätého Cyrila i pred menom svätého Metoda, opät však išlo o velmi ojedinelé výskyty. ${ }^{25}$

\section{Záver}

V príspevku sme sa venovali otázke používania singulárového i plurálového tvaru atribútu svätý pred menami Cyril a Metod. Hoci slovenská gramatika nevylučuje ani podobu svätý Cyril a Metod, v ktorej sa použitie singulárového tvaru prívlastku odôvodňuje elipsou slova svätý pred menom Metod, ani podobu svätí Cyril a Metod, ked’ sa prívlastok svätí vztahuje na obe mená viacnásobného člena, pokúšali sme sa na základe analýzy používania týchto podôb v textoch piesní a modlitieb, ako aj v textoch SNK zistit, či možno jeden z variantov svätý Cyril a Metod - svätí Cyril a Metod (vrátane jednotlivých singulárových i plurálových pádových tvarov) charakterizovat ako preferovaný, resp. častejšie používaný.

Z analýzy uvádzania spojení svätý/svätí Cyril a Metod (i dalších analogických spojení s menami iných svätých) v žánroch piesní a litánií publikovaných v rôznych vydaniach $J K S$ vyplynulo, že prívlastok svätý sa používa v singulárovom tvare vtedy, ak je prvá čast’ viacnásobného člena uvedená v singulárovom tvare mena (napr. Svätý Cyril a Metod; Svätý Andrej Svorad a Benedikt; Svätý Michal, Gabriel a Rafael). Ako sme uviedli, v závažných náboženských textoch, ku ktorým podla svojho názoru môžeme priradit i cirkevne schválené formulácie modlitieb, konkrétne litánie, svoju úlohu nepochybne zohráva i tradícia, ktorá sa môže prejavovat i snahou o jednotné a nemenné používanie najmä všeobecne známych, rozšírených a vžitých modlitieb. Netreba tu však zabúdat ani na vplyv všeobecne uznávaného a prijímaného $J K S$ vo verejnosti s katolíckym vierovyznaním.

Analýza frekvencie výskytu singulárových a plurálových tvarov prívlastku svätý pred menami Cyril a Metod v dvoch korpusoch SNK dokázala, že podstatne častejšie sa pred spojením Cyril a Metod používa plurálová podoba uvedeného prívlastku, a to nielen v hlavnom korpuse PRIM9, obsahujúcom texty rôzneho tematického i žánrového pôvodu, ale aj v korpuse náboženských textov BLF2. Môžeme teda zhodnotit, že i ked’sa v jednotlivých vydaniach JKS uvádza podoba svätý Cyril a Metod (a aj d’alšie analogické spojenia mien svätých) so singulárovým tvarom prívlastku svätý, neznamená to, ako na to poukazujú aj výsledky analýzy textov náboženského charakteru v $S N K$, že by sa všeobecne v textoch náboženského pôvodu výhradne uprednostňovala podoba so singulárovým prívlastkom svätý. S výnimkou modlitieb a piesní publikovaných v JKS

korpuse zo 7 výskytov zaznamenali singulárový tvar prívlastku svätý opät len 1-krát. V korpuse BLF2 sme pri oboch zápisoch zaznamenali iba plurálové tvary prívlastku svätý: v prípade zápisu svätí Konštantín Cyril a Metod išlo o 7 výskytov a zápisu svätí Konštantín-Cyril a Metod o 3 výskyty. Iné príbuzné zriedkavé výskyty, ktoré sme zaznamenali: svätí Cyril-Konštantín a Metod (2 výskyty v PRIM9, 2 výskyty v BLF2); svätí Cyril Konštantín a Metod (2 výskyty v PRIM9, 2 výskyty v BLF2); svätý Konštantín Filozof a Metod (1 výskyt v PRIM9, 1 výskyt v BLF2); svätý Cyril-Konštantín a Metod (1 výskyt v PRIM 9, žiadny výskyt v BLF2). Jednotlivé zápisy uvádzame kvôli prehladnosti v nominatívnom tvare, v konkrétnom výskyte sa však mohol daný tvar nachádzat v lubovolnom páde, teda zápis svätý zastupuje lubovolný singulárový pádový tvar tohto prívlastku, zápis svätí zastupuje lubovolný plurálový pádový tvar.

25 Uvádzame len podoby spojení, ktoré sme zaznamenali (singulárový prívlastok v N opät zastupuje všetky singulárové pádové tvary, plurálový prívlastok $\mathrm{v} \mathrm{N}$ zastupuje všetky plurálové pádové tvary): svätý Konštantín a svätý Metod (3 výskyty v PRIM9, 2 výskyty v BLF2); svätý Cyril Konštantín a svätý Metod (2 výskyty v PRIM9, 3 výskyty v BLF2); svätý Konštantín-Cyril a svätý Metod (1 výskyt v PRIM9, 1 výskyt v BLF2); svätý Konštantín Filozof a svätý Metod (1 výskyt v PRIM9, 1 výskyt v BLF2). 
formulujeme teda tézu o všeobecnej preferencii plurálových podôb prívlastku svätý pred menami Cyril a Metod, a to bez ohladu na tematické zameranie textu (nábožensky orientovaný text alebo iný typ textu). Treba však vziat do úvahy aj možnost', či zistená preferencia plurálových tvarov v SNK nesúvisí najmä s tým, že sme vychádzali z výskumu písaných textov (skúmané korpusy PRIM9 i BLF2 obsahujú písané texty; porov. pozn. 12 a 13). Pri použití plurálového tvaru prívlastku svätý v písanom texte môže totiž autora ovplyvnit napr. domnienka, že takýto tvar je azda gramaticky „správnejší, resp. „dôslednejší‘. Možno tu teda uvažovat ešte o hypotéze, či v hovorenej reči, naopak, nedominujú skôr podoby analyzovaných spojení so singulárovými tvarmi prívlastku svätý. Na overenie tejto hypotézy však v súčasnosti nemáme dostatok relevantných výskumných údajov, pretože verzia korpusu hovorených textov s-hovor-6.0 $0^{26}$ obsahuje velmi nízky počet výskytov spojení svätý/svätí Cyril a Metod na to, aby bolo možné na základe komparácie používania singulárových i plurálových tvarov prívlastku svätý v korpusoch písaných i hovorených textov vyvodit relevantné závery, navyše prekážkou takejto komparácie je aj zvuková zhoda tvarov svätý - svätí. ${ }^{27}$

\section{REFERENCES}

\section{Primary sources}

Blumentál. 2011. Blumentál. In Slovenský národný korpus - prim-9.0-public-sane. Bratislava. https://korpus.juls.savba.sk.

Hospodárske noviny. 2010. Hospodárske noviny. In Slovenský národný korpus - prim-9.0-publicsane. Bratislava. https://korpus.juls.savba.sk.

JKS. 1937. Jednotný katolícky spevník. Trnava.

JKS. 1944. Jednotný katolícky spevník s najpotrebnejšími modlitbami pre krestanov-katolíkov. Trnava.

JKS. 1950. Jednotný katolícky spevník s najpotrebnejšími modlitbami pre krestanov-katolíkov. Trnava.

JKS. 1969. Jednotný katolícky spevník. Trnava - Bratislava.

${ }^{26}$ Hovorený korpus s-hovor-6.0 má rozsah 6 mil. 593-tisíc textových jednotiek a je prístupný od 30. novembra 2017. Obsahuje 760 nahrávok (viac ako 714 hodín zvukových záznamov) (Slovenský hovorený korpus 2021).

27 Z 29 výskytov (i.p.m.: 4,40; ARF: 13,13) spojenia svätý Cyril a Metod (v rôznych pádových tvaroch) v korpuse s-hovor-6.0 sa plurálový tvar prívlastku svätý pred menami Cyril a Metod nachádzal iba 1-krát (išlo o tvar svätým Cyrilovi a Metodovi). I tento pomer by teda mohol poukazovat na presne opačnú tendenciu v porovnaní s písanými textami, a to na preferenciu singulárových podôb prívlastku svätý. Pri analýze prepisov hovorených prejavov však existuje ešte jeden problém - ide o zápis zvukovo zhodných singulárových i plurálových tvarov svätý - svätí, kedže obe podoby, ako sme už uviedli, sa vyslovujú tvrdo. Pravda, nepredpokladáme ani to, že by bežný hovoriaci pri vyslovení tohto spojenia (nie jeho prečítaní z písanej predlohy) premýšlal nad tým, či vyslovil prívlastok svätý v singulári alebo v pluráli, pretože z hladiska hláskoslovnej realizácie sa tieto varianty nelíšia. Pri prepisovaní nahrávok predpokladáme tendenciu uvádzat prívlastok svätý v jeho základnom singulárovom tvare (v korpuse s-hovor-6.0 sa nachádzajú 3 výskyty nominatívneho spojenia svätý Cyril a Metod, nominatívna podoba svätí Cyril a Metod sa tu nenachádza ani raz). Aj tento faktor teda vyvoláva otázky o zmysluplnosti analýzy tejto problematiky na materiáli hovorených textov, resp. o výpovednej hodnote takýchto výsledkov. Zmysel by malo porovnat len výskyty v nepriamych pádoch (všetkých okrem nominatívu), ak by bol, samozrejme, počet výskytov v tomto korpuse dostatočne reprezentatívny. 
JKS. 1971. Jednotný katolícky spevník s najpotrebnejšími modlitbami pre krestanov katolíkov. Trnava - Bratislava.

JKS. 1992. Jednotný katolícky spevník s najpotrebnejšími modlitbami pre krestanov katolíkov. Trnava.

JKS. 2012a. Jednotný katolícky spevník a najpotrebnejšie modlitby krestana katolíka. Trnava.

JKS. 2012b. Jednotný katolícky spevník a najpotrebnejšie modlitby krestana katolíka. Trnava.

In Slovenský národný korpus - prim-9.0-public-sane. Bratislava. https://korpus.juls.savba.sk. JKS. 2018. Jednotný katolícky spevník a najpotrebnejšie modlitby krestana katolíka. Trnava.

Katolícke noviny. 2010. Katolícke noviny. Trnava. In Slovenský národný korpus - prim-9.0-publicsane. Bratislava. https://korpus.juls.savba.sk.

Katolícke noviny. 2013. Katolícke noviny. Trnava. In Slovenský národný korpus - prim-9.0-publicsane. Bratislava. https://korpus.juls.savba.sk.

Liba, Peter - Lauková, Silvia (eds.). 2012. Svätý Cyril a svätý Metod v slovenskej literatúre. Výberová antológia. Nitra.

MY Naše novosti. 2017. MY Naše novosti. Bratislava. In Slovenský národný korpus - prim-9.0public-sane. Bratislava. https://korpus.juls.savba.sk.

MY Hornonitrianske noviny. 2013. MY Hornonitrianske noviny. Bratislava. In Slovenský národný korpus - prim-9.0-public-sane. Bratislava. https://korpus.juls.savba.sk.

MY Liptovské noviny. 2011. MY Liptovské noviny. Bratislava. In Slovenský národný korpus prim-9.0-public-sane. Bratislava. https://korpus.juls.savba.sk.

MY Žilinské noviny. 2015. MY Žilinské noviny. Bratislava. In Slovenský národný korpus - prim9.0-public-sane. Bratislava. https://korpus.juls.savba.sk.

Slovenský národný korpus - blf-2.0. 2014. Slovenský národný korpus - blf-2.0. Bratislava. http:// korpus.juls.savba.sk.

Slovenský národný korpus - prim-9.0-public-sane. 2020. Slovenský národný korpus - prim-9.0public-sane. Bratislava. http://korpus.juls.savba.sk.

Slovenský hovorený korpus - s-hovor-6.0. 2017. Slovenský hovorený korpus - s-hovor-6.0. Bratislava. http://korpus.juls.savba.sk.

Slovo medzi nami. 2008. Slovo medzi nami. Bratislava. In Slovenský národný korpus - prim-9.0public-sane. Bratislava. https://korpus.juls.savba.sk.

SME. 1995. SME. Bratislava. In Slovenský národný korpus - prim-9.0-public-sane. Bratislava. https://korpus.juls.savba.sk.

TK KBS. 2006. Tlačové správy z www.tkkbs.sk. Bratislava. In Slovenský národný korpus - prim9.0-public-sane. Bratislava. https://korpus.juls.savba.sk.

TK KBS. 2009. Tlačové správy z www.tkkbs.sk. Bratislava. In Slovenský národný korpus - prim9.0-public-sane. Bratislava. https://korpus.juls.savba.sk.

TK KBS. 2010. Tlačové správy z www.tkkbs.sk. Bratislava. In Slovenský národný korpus - prim9.0-public-sane. Bratislava. https://korpus.juls.savba.sk.

TK KBS. 2011. Tlačové správy z www.tkkbs.sk. Bratislava. In Slovenský národný korpus - prim9.0-public-sane. Bratislava. https://korpus.juls.savba.sk.

TK KBS. 2012. Tlačové správy z www.tkkbs.sk. Bratislava. In Slovenský národný korpus - prim9.0-public-sane. Bratislava. https://korpus.juls.savba.sk. 


\section{Secondary sources}

JazykovaPoradna.sk. 2013. Ako sa správne číta skratka sv. v názve Pedagogickej školy sv. Cyrila a Metoda? https://jazykovaporadna.sme.sk/q/3764/.

JKS. 2018. Jednotný katolícky spevník a najpotrebnejšie modlitby krestana katolíka. Trnava.

Masár, Ivan. 1991. Svätý Cyril a Metod či svätí Cyril a Metod, orodujte za nás! In Kultúra slova 25/5, 316-317.

Korpus náboženských textov. 2021. Korpus náboženských textov. Bratislava. https://korpus.sk/blf. html.

Oravec, Ján - Bajzíková, Eugénia. 1986. Súčasný slovenský spisovný jazyk. Syntax. Bratislava.

Slovenský hovorený korpus. 2021. Slovenský hovorený korpus. Bratislava. https://korpus.sk/shk.html.

Štruktúra korpusu prim-9.0. 2021. Štruktúra korpusu prim-9.0. Bratislava. https://korpus.sk/ $\operatorname{prim}(2 \mathrm{~d}) 9(2 \mathrm{e}) 0 . \mathrm{html}$.

Štruktúra Slovenského národného korpusu. 2021. Štruktúra Slovenského národného korpusu. Bratislava. https://korpus.sk/res.html.

Šimková, Mária. 2017. 6. Výberový slovník termínov a pojmov z korpusovej lingvistiky. In Šimková, Mária et al. Slovenský národný korpus. Texty, anotácie, vyhl’adávania. Bratislava, 135-149.

Vaňko, Juraj. 2015. Syntax slovenského jazyka. Nitra.

Verejne prístupné korpusy SNK. 2021. Verejne prístupné korpusy SNK. Bratislava. https://korpus.sk/ structure1.html.

Welnitzová, Katarína - Munková, Daša - Wrede, Olga. 2020. Chybovost’ v predikatívnosti a kvalita strojového prekladu. In Jazyk a kultúra 11/41-42, 160-172. https://www.ff.unipo.sk/jak/ 41-42_2020/Katarina_Welnitzova_Dasa_Munkova_Olga_Wrede_studia.pdf.

Mgr. Patrik Petráš, PhD.

Constantine the Philosopher University in Nitra

Faculty of Arts

Department of Slovak Language and Literature

Štefánikova 67

94974 Nitra

Slovakia

ppetras@ukf.sk

ORCID ID: 0000-0003-3946-5596

WOS Researcher ID: AAO-7616-2020

SCOPUS Author ID: 57193956532 